\title{
Opposing violent extremism through counter-narratives: Four forms of narrative resistance
}

\author{
Sveinung Sandberg, University of Oslo, Norway \\ sveinung.sandberg@jus.uio.no \\ Jan C. Andersen, University of Oslo, Norway \\ jan.c.andersen0202@gmail.com
}

This is a postprint version of chapter $22(p .445-466)$ in

Emerald Handbook of Narrative Criminology (2019)

eds. Jennifer Fleetwood, Lois Presser, Sveinung Sandberg and Thomas Ugelvik.

\section{ABSTRACT:}

Following recent terrorist attacks in the US and Europe, Western Muslims have been criticized for not taking a firm stand against radical Islam and extremist organizations. Drawing on insights from narrative criminology, we challenge such assertions and reveal Muslims' narrative mobilization against violent jihadism. Based on 90 qualitative interviews with young Muslims in Norway, we show how violent extremism is rejected in a multitude of ways. This narrative resistance includes criticizing extremist jihadist organizations for false interpretations of Islam and using derogatory terms to describe them. It also includes less obvious forms of narrative resistance, such as humour and attempts to silence jihadist organizations by ignoring them. While narrative criminology has effectively analysed the stories that constitute harm, less attention has been paid to narratives that counter harm. We argue that stories that counter jihadi narratives are crucial to understand the narrative struggles of Muslim communities, whose outcomes can help determine why some individuals end up becoming religious extremists - while others do not. By distinguishing between factual, emotional and humorous counter-narratives and describing silence as a form of resistance, we show resistance to extremism that is often concealed from the public and the state. 
RUNNING HEADER: Narrative Resistance

KEYWORDS:

1. Counter-narrative

2. Narrative resistance

3. Extremism

4. Islam

5. Team research

6. Interviews 


\section{Introduction:}

Extremist jihadist groups have dominated the media since the terrorist attacks on the US on September 11, 2001. The rise of the Islamic State (IS) ${ }^{1}$ in 2014 further increased the already extensive news coverage. For many outsiders, this presence has further bolstered a conflating of the religion of Islam with jihadist organizations, portraying the former as violent and totalitarian. Studying Western media, Ahmed and Matthes (2017, p. 219) show that Muslims "tend to be negatively framed, while Islam is dominantly portrayed as a violent religion." This portrayal in media can lead to Muslims feeling unjustly defined as a threat to national security (Mythen et al. 2012). Backing that sentiment, Kearns, Betus \& Lemeiux (2017) reveal that the word terrorism is more widely used in cases where the perpetrator is Muslim and that these cases receive media coverage that is four and a half times as great as that when the perpetrator is a non-Muslim.

The skewed media coverage creates and reinforces cultural notions of what and who should be feared. It alienates Muslims in general and may "further enhance intergroup conflicts between Muslims and non-Muslims” (Von Sikorski, Schmuck, Matthes \& Binder, 2017). As part of a package that treats all Muslims as guilty, Muslims are being asked to account for acts of violence committed in the name of Islam (van Es, 2018). Many young Muslims consider doing so to be an unreasonable expectation and say that media coverage of Islam and social pressure ruins their quality of life and sense of belonging in Western societies. Western Muslims often refuse to denounce extremist groups. They believe it is not their responsibility, and argue that these groups have nothing to do with Islam (Sandberg et al., 2018). Their public silence has sometimes been interpreted as support, and Muslims have

\footnotetext{
${ }^{1}$ Also known as ISIS, ISIL or Daesh.
} 
been criticized for not taking a clearer stance against terrorism and religious extremists (e.g. Maidment, 2017; Von Sikorski et al, 2017).

This chapter explores how young Muslims reject jihadist organizations and points to the value of studying counter-narratives in general populations instead of focusing on the dominant narratives that are reproduced in media and public representations. The Muslims we interviewed expressed their opposition to religious extremism not primarily through loud protests or large mobilizations aimed at creating media attention; rather, it emerged in everyday stories about religion and politics. There is an ongoing narrative struggle on how to understand Islam in Muslim communities. Combined with factors such as social and economic marginalization, international and national politics, and social networks, the outcome of this narrative struggle explains the prevalence of religious extremism. Like all ideologies, Jihadist ideology is primarily narrative in its structure (Halverson, Goodall \& Corman, 2011), which makes narrative analysis and narrative criminology central for terrorism studies. Narratives nurture the motivation to do harm and ignore harm by others (Presser 2018), but telling stories can also be an important way to resist criminogenic and harmful ideologies.

Drawing on qualitative interviews with 90 young Muslims in Norway, we show the ways in which young Muslims reject violent extremist organizational actions and rhetoric. Their opposition to extremism varied from calmly and factually disproving such religious practice and theology, to using highly emotional language containing derogatory terms, humour and ridicule. Sometimes they attempted to ignore terrorist organizations and rhetoric altogether. We describe these counter-narratives as narrative resistance, emphasizing how the stories of "ordinary" people can limit harm and challenge harm-doers. In terms of method, we touch upon how to research counter-narratives and the advantages of qualitative team research in narrative studies. 


\section{NARRATIVE ANALYSIS, POWER AND RESISTANCE}

Narrative criminology has approached narratives in different facets (Sandberg, 2016) but has tended to emphasize narratives that may induce harm. In the initial conception of narrative criminology, however, the emphasis was on stories that perform the work of "instigating, sustaining, or effecting desistance from, harmful action” (Presser \& Sandberg, 2015, p. 1). That is, opposition to harm was on the agenda for research. The research preceding narrative criminology studied desistance (Maruna, 2001); however, one notable Canadian exception notwithstanding (Joosse, Bucerius, Thompson, 2015), few works within narrative criminology have studied resistance to criminal and harmful action by non-offenders or the narrative struggles preceding engagement in harm.

Narratives are discourses that link one or more events temporally and causally (Polletta, Chen, Gardner \& Motes, 2011). We believe that narratives are extraordinary forms of discourse, due to their potential for captivating narrators and arousing audiences (Presser, 2018). Characters are an essential part of narratives. Most stories include one or several easily recognizable characters, such as "the villain" or "the imposter" in folk-tales, that are crucial for understanding the plot and morale of the story (Propp, 1968). Narratives sometimes appear as complete stories, which most people associate with narrative analysis, but in real life, narratives often appear as tropes, or "single words or short phrases that only hint at familiar stories" (Sandberg, 2016, p. 155). In contemporary Western society tropes such as "Islamic terrorism", can be used to identify stories that are so widespread that they need not be spelled out every time they are evoked. Another fundamental, but often-neglected part of narrative analysis, is narrative performances. Stories are not only transmitted through words, 
but also gestures, body language, tone of speaking etc. (Baumann, 1986). These displays of emotions are sometimes followed by the use of derogatory terms, as we will return to later.

The intense emotions that accompanied many of the stories in this dataset suggest that interviewees felt that they were up against powerful master narratives about Islam. A master narrative is one that is "deeply embedded in a culture, provides a pattern for cultural life and social structure, and creates a framework for communication about what people are expected to do in certain situations" (Halverson et al., 2011, p. 7). What counts as a master narrative varies depending on context; different master narratives pertain in different situations, and they can sometimes conflict with each other. Sometimes it is relatively easy to identify a master narrative, as with stories of motherhood and pregnancy depicted in early work on narrative resistance (Talbot, Bibace, Bokhour \& Bamberg, 1996). At other times, it is more difficult: What counts as master narratives is to a large degree a question of interpretation and in many cases, it is better for researchers to argue it thoroughly or show it empirically instead of assuming their presence. In narrative analysis, the concepts of master narrative or even hegemony (Laclau \& Mouffe, 1985) are important because they open up thinking about domination in a research field that is often accused of neglecting issues of power.

While conceptualising master narratives can be a way to identify powerful moments of consensus in society, researching counter-narratives shows the many ways that this ideological domination can be challenged. Counter-narratives exist in close relation to master narratives but these two types of narratives are not "necessarily dichotomous entities" (Andrews, 2004). Instead, they are intertwined in complex ways; for example, a master narrative can be challenged through appeal to other master narratives or by working critically with components of them, providing new direction and meaning. Individuals and groups can mirror or challenge a master narrative, or develop it using their own personal stories (Andrews, 2002, see also Bamberg, 2004). The association of Islam with war and terrorism 
for example, is thematised in a prominent master narrative, but is also continuously challenged by counter-narratives in public discourse and opposed in narrative work on senses of self and social identities among Muslims.

Paradoxically, the idea of Islam as a religion of war and terrorism is shared by both jihadi extremist and anti-Islamic rhetoric (Ekman, 2015; Shaffer, 2016; Page, Challita \& Harris, 2011). The two master narratives that the young Western Muslims we interviewed countered were first, a jihadi master narrative that uses narratives of Muslim victimhood and religious apocalyptic utopianism to conclude that war and terror are justified, even inevitable, because Islam is at war with the West (Halverson et al., 2011; Karmon, 2015; McCants, 2015); and second, a Western master narrative based on the assumption that Islam is a singular world religion, and ideas of racial inferiority with a long history in Western societies, concluding that 'Muslims are terrorists' (e.g. Ahmed \& Matthes, 2017; Kearns et al. 2017; Aydin, 2017). Islam is for example routinely associated with terrorism through the term "Islamic terrorism", promoting "the widely accepted 'knowledge' that certain forms of Islam are by nature violent and terroristic" (Jackson, 2007, p. 405).

The frequency and urgency of the young Muslim interviewees' stories countering extremism indicate that these stories are of great importance to them. In this regard, we agree with Joosse et al. (2015, p. 815) that "the most powerful counternarratives that work against radicalization will already be in place within communities, reacting against the ideologies and radicalization strategies of terrorist movements." We describe the counter-narratives to which we gained access in our interviews as narrative resistance to master narratives that describe Islam as a religion of war and terrorism. Our main aim in this chapter is to explore these forms of "everyday" narrative resistance, to understand how narratives not only promote but also constrain harm. When extreme beliefs are challenged by friends, family or others who 
are socially, religiously or ideologically close to those holding them, it is more effective than when they are confronted by outsiders.

\section{STUDY AND PARTICIPANTS}

The participants in this study were 90 young Muslims in Norway aged 18 to 32 years old; half of them were women and half men. The main criteria for participation was age and that the subjects defined themselves as Muslims. Given the aim to research the everyday counternarratives of young Muslims, we tried to avoid activists, imams or other religious experts and leaders. The goal was to recruit and get access to the counter-narratives of what we for want of a better word describe as "ordinary” Muslims. This research focus also made it important to talk to young people instead of searching for coverage in newspapers or comments online. Open source data are often shaped by a public or (social) media context and usually comes with a heavy selection bias in favour of the more "activist" and "extreme" voices.

The interviews were conducted throughout Norway in 20 different municipalities. Most of the interviews took place in the capital, Oslo, or the surrounding areas, where most Norwegian Muslims live. It is estimated that approximately 200,000 people identify as Muslims in Norway, representing approximately 4 percent of the population (Østeby \& Dalgard, 2017). The participants in our study had backgrounds from 20 different countries, the most numerically prominent being Morocco, Somalia and Pakistan. Most of the young Muslims were Sunni (73), but we also interviewed Shiites (8) and those declaring some smaller Muslim affiliations. Some participants did not want to state their religious affiliation, for example because they refused to differentiate between what they described as "sectarian" affiliations within Islam. 
A team of five researchers, three women and two men, from different cultural and academic backgrounds and with religious affiliations and beliefs, carried out the interviews, which were conducted over a 6-month period, from January to June 2017. Although it might be expected that the gender, religious and cultural backgrounds of the interviewer would impact the narrative, for example whether interviewers were Muslims, ethnic minority or ethnic majority, in fact respondents' narratives were more similar than different (see also Damsa \& Ugelvik, 2017). The different ways in which Muslims rejected extremist narratives were often the same, and seemed to reflect a narrative habitus (Fleetwood, 2016) - their structured and embodied ways of experiencing and acting in the world - rather than specific responses in and to the interview situation.

The interviews lasted between one and two hours and were held in cafés or participants' homes. The interviewees were recruited using social networks, referral by university students, and social media such as Facebook, by contacting mosques and Muslim youth organizations and seeking out Muslim events. Interviewers followed a semi-structured interview guide on themes including positive Islamic narratives, marginalization and discrimination, jihadi narratives, extremist organizations and de-radicalization. The interviews were designed to elicit storytelling: rather than having a checklist of questions, and the interviewers were encouraged to start a conversation about the aforementioned themes. Unlike many surveys of Muslims (e.g. Vestel \& Bakken, 2016), where participants are encouraged to answer categorically yes or no if they support controversial themes such as sharia, and whether the West is at war with Islam, we attempted to elicit more nuanced answers to such controversial questions. Therefore, establishing trust was paramount. We did this by recruiting through interviewers' own social networks, establishing contact in advance of interviews and attempting to do interviews on premises where interviewees felt comfortable. Most importantly, we tried to create an atmosphere in interviews where 
participants felt free to state their opinions and explore controversial issues through storytelling.

\section{THE PROS AND CONS OF TEAM RESEARCH}

Team research is especially useful in studies such as ours where the aim is to include many participants in a limited period of time and where participants are difficult to recruit or are spread out over a large geographical area. While qualitative researchers should not strive to make their samples representative, having a large sample makes it easier to obtain variety and to gain a sense of whether what is described is a widespread or a more individually or regionally specific phenomenon. In narrative studies where the primary interest is in the narrative repertoires of groups, societies and cultures, large qualitative samples can be useful to obtain a large variety of stories, and have the same story told in various ways to observe the different "shapes" that it can take. It also makes it easier to gain a sense of which stories are the most important and to "control" for interviewer-effects. In our study, comparable stories coming forth in interviews with researchers of different age, gender, and cultural and religious background strengthens our view that they are not the result of any particular interview combination but rather pivotal narratives salient in Muslim communities.

Having a research team also means that there is a continuous discussion of how to interpret the research results after interviews, which is an advantage compared to research conducted by a single researcher. Our team included Muslims, others with great expertise in Islam and the associated language and culture - and researchers with other backgrounds and academic expertise. When doing qualitative research there are advantages of both being an insider and outsider (Bucerius, 2013), and team research can get the best of both. For example, when reading or listening to interview extracts we could sometimes discuss single 
words or expressions (e.g. in Arabic) for hours to agree upon an interpretation of how and why they were used. It was of great value to have a diverse team when interpreting complex narratives that often came in the form of tropes. Group research forces one to continuously challenge one's own presumptions and preliminary conclusions. These ongoing discussions and the experiences from the different interviewer-interviewee combinations strengthen the validity of the research conclusions. On a different note, qualitative research is also often a solitary and lonely project and team research can make research more social and fun.

While there are many advantages, there are naturally disadvantages to team research. It takes a considerable amount of logistics and organizing, the interviewers need to be trained and followed up closely, and there is always the risk that individual researchers do things so differently that comparison across interviews is difficult. Having many researchers involved in studying sensitive and personal topics can also result in conflicts within the group. Coauthoring was in our experience more difficult than doing interviews as part of a team, and one should consider the advantages and disadvantages of having "too many cooks" when writing and if choosing to do so, one should have a clear plan for how to go about it. However, based on this study and on our previous experience with team research projects studying different populations such as children in school, cannabis users, binge drinkers and large-scale imprisoned drug dealers, we strongly recommend team research for narrative studies.

\section{FORMS OF NARRATIVE RESISTANCE}

Through narrative team research (Sandberg et al., 2018), we discovered four ways that interviewees rejected religious extremism: disputing the jihadist rhetoric and interpretation of Islam on factual grounds, using derogatory, often highly expressive language to dismiss 
religious extremism, making fun of extremists, and trying to ignore their presence. ${ }^{2}$ Taken together, our results show the variety of ways extremism is opposed and rejected narratively in Muslim communities. More generally, they reveal the various forms that counternarratives can take.

\section{FACTUAL COUNTER-NARRATIVES}

The jihadi master narrative is based on the premise that Islam is under attack by the West and secular forces in Muslim countries, requiring Muslims to defend the religion by force. Jihadi organizations argue that terrorism and political violence are proportionally just and religiously sanctified countermeasures in an ongoing war against the kuffar, or disbeliever (Leuprecht, Hataley, Moskalenko \& McCauley, 2009). They also proclaim a strict interpretation of sharia as a repressive set of laws that should be deeply and comprehensively implemented in society, through the use of force if necessary (McCants, 2015). The majority of our participants opposed the general idea that the West was at war with Islam as well as violent and authoritarian interpretations of Islamic law. They disputed the jihadist account of Islam versus the West on factual grounds, by criticizing the theological interpretations, the principles and the practices of Islamic teachings advocated by jihadi organizations. They adamantly insisted that jihadi organizations in no way or form represented Islam.

Yasmin, ${ }^{3}$ a twenty-four-year-old Norwegian-Pakistani woman, argued that extremists "abuse Islam in the worst kind of way." Karim, a twenty-five-year-old Norwegian-Algerian man, made a similar point about the IS in particular:

\footnotetext{
${ }^{2}$ It was most often directed against the IS, the jihadist organization that dominated the news at the time of the interviews.

${ }^{3}$ All names are pseudonyms
} 
It's really a war for their own interests, to get rich. Because when they took control of more land in Iraq or Syria, I think, the first thing they did was to secure the oil wells. So, this says it all. That is, they were not aiming to establish social justice or a fair society, no. They are simply there just to have their piece of the pie. That's it. It's just that they use religion or not that they use religion but, rather, their own ideology. Those kinds of people have nothing to do with Islam.

By alleging that the IS has primarily acted only to secure its own economic interests, Karim dismissed it as being a truly Islamic organization. It was important for our participants to explain that extremists do not represent Muslims and that they in fact act contrary to the teachings of Islam.

Jihadi organizations are known for their violence and brutality. The IS is especially notorious for its violent actions, displaying brutality not only as a by-product of war but also as a deliberate strategy (Byman, 2015). Terrorist organizations can use spectacles of violence to draw attention and supporters to their cause, but in doing so they risk losing mainstream support (Andersen \& Sandberg, 2018). Indeed, the use of excessive violence displayed by the Somali group al-Shabaab has led the Somali diaspora in Canada to reject the organization (Joosse et al., 2015). The excessive and violent behaviour perpetrated by jihadi organizations was a major point of critique for the young Muslims whom we interviewed. Mina, a twentyyear-old Norwegian-Somali woman, stated:

I feel that the IS is using Islam. They don't follow Islam. They use the word "Islam," saying that they are Muslims, but they don't follow any of it. They kill lots of innocent Muslims every single day and torture and rape. It's like all that Islam says you should not do, they do. 
For these young Muslims, violence was only legitimate in situations of self-defence, and they labelled jihadists as Muslim imposters because they failed to follow what they saw as the teaching of the Quran. Such characteristics are an efficient way to draw borders between "good" and "bad" people and sanction behaviour. Young Muslims frequently categorized jihadists as imposters who cynically misused the religion of Islam (see also Joosse et al., 2015). Sana, a nineteen-year-old Norwegian-Moroccan woman, highlighted the difference between "a real Muslim" and the IS:

In the Quran, it says that one should not kill anyone or harm anyone. Not rape women, or force women, things like that. If you were one hundred percent Muslim, you would not do such things. But still they bomb people. Children who are innocent. Tell me where in the Quran it says that you must kill a baby and the world will be better? No, because a real Muslim wouldn't have done anything like that. He wouldn't hurt a little insect or spider.

Ayan, a twenty-two-year-old Norwegian-Somali woman, similarly rejected violent actions committed in the name of Islam, referring to verse 5:32 of the Quran: "Killing a human being - it does not matter what religion he or she is - is like killing all humanity," she said. Many of our participants referred to the same Quran verse and described Islam as a peaceful religion and "real" Muslims as peaceful. To emphasize the importance of human dignity in Islam, the young Muslims referred to another phrase that also originated from verse 5:32 in the Quran: "If you save a human being, it is like saving all mankind." That extremist groups break with these principles was an important part of the argument for why they did not represent Islam. 
Extremism is often linked to a conservative understanding of Islam. Nevertheless, there was a widespread scepticism about the IS even among the most conservative young Muslims whom we interviewed. Abdulllah, an eighteen-year-old Norwegian-Somali man, self-identified as Salafi, an ultra-conservative interpretation of Islam. He expressed a more literate and sophisticated theological opposition to jihadi extremism, which differed from Muslims with less literate knowledge about Islam. Abdulllah explained, "When talking about hadith and different types of classifications of authentic hadith, the IS has used a lot of hadith that is daif," which means that the source material has little credibility (Barlas, 2002). Abdullah then argued against the IS' theological interpretation of judgement day:

Among other things, that there will be black flags rising, that it will be an army, that they will be fighting in Afghanistan. ${ }^{4}$ All this is daif. That is not something you can accept. So, hadith scholars have classified hadiths. Among the hadiths that are declared daif are the hadiths that the IS uses. So, people think that this is true, that the Prophet has said they should go there [to Syria].

Abdullah emphasized that supporters of the IS hide theological facts and use religious texts with little credibility. Like Abdullah, other young Muslims we interviewed referred to theological concepts using specific Arabic words or expressions to show their knowledge and expertise of Islam. This can be seen as highly effective symbolic boundary work to cultivate differences between Muslim in-groups and out-groups (Essers \& Benschop, 2009). Many young Muslims denounced extremist jihadist group by questioning their use of sources and

\footnotetext{
${ }^{4}$ The flags IS use refers to a story of how an army lead by the Muslim Mahdi (Messiah) is prophesised to emerge under the black flag before the end of the world. In a decisive battle, Muslim forces will achieve victory against the enemies of Islam to restore the glory of Islam (Bahari \& Hassan, 2014). The emergence and success of the IS is often attributed to the promotion of an apocalyptic worldview, describing how we are approaching the end of history (McCants, 2015).
} 
theological interpretations; their use of Arabic expressions demonstrated their own knowledge of Islam.

Amal, a twenty-four-year-old Norwegian-Moroccan woman, criticized jihadists for "picking-and-choosing" when they advocated violent and authoritarian interpretations of Islamic law. In explaining the meaning of "true" Islam as peaceful, many young Muslims also emphasized that Islam was consistent with international laws of war. Mustafa, a twentyseven-year-old Norwegian-Moroccan man, pointed out that Islam contains "rules when it comes to war and the treatment of other people who are not engaging in war against you." He elaborated on how extremist groups violate these rules:

If someone who is fighting against you loses his weapon or doesn't have any weapons and surrenders, then you have no right to do anything to him. You can capture him as a hostage and feed him as a guest. You have to feed him well, let him sleep well, and later release him so he can go back to his family. At the same time, if you fight someone and kill him, then you're not allowed to cut his body up in pieces. If he dies, then the body is supposed to be whole and delivered to his family, or you have to allow the others who are fighting against you to stop the war so they can take his body so they can bury him.

This understanding of the humane and peaceful aspect of Islam even in the midst of combat, constructed an immense divergence between his version of Islam and that of jihadist organizations.

In a Dutch analysis of newspaper articles concerning Muslims in media, van Es (2018) argues that they emphasized the humane dimension of Islam and framed Islam as a religion of peace as a direct response to the continuous call on Muslims to denounce 
terrorism. Stories depicting "peaceful Islam" are important counter-narratives disputing a master narrative promoted by jihadi and anti-Islamic rhetoric alike, stating that Islam promotes political violence and terrorism. With time and as they spread, these counternarratives can change the meaning of the phenomena itself. Muslims for example, sometimes counter widespread "negative" narratives of Islam by fundamentally redefining their own understanding of what the religion is (van Es, 2018). Stories emphasizing that "Islam is peace" can emerge as counter-narratives but then gradually become master narratives in their own right.

This group of young Muslims in Norway argued calmly and factually against both the theology and the religious practice of jihadist organizations. In an ongoing narrative struggle with extremists and in an attempt to take control of their Muslim identity, they rejected violent extremism as being part of Islam. The most important way in which they did so was by stating that terrorism had nothing to do with Islam and by criticizing the violence used by jihadist organizations. Counter-narratives that factually reject or challenge master narratives appeal to what Aristotle (2010) described as logos or reasoning. In such means of persuasion, stories were often used to show that the narrator knows better than those being opposed. Importantly, narrative resistance is not only about language, but also closely connected to body language and narrative performance. In discussions characterised by factual counternarratives for example, it can be a pointed choice to stay calm and not be carried away by emotions to demonstrate a superior intellectual position. Such counter-narratives can therefore sometimes be opposed to those we discuss below.

\section{EMOTIONAL COUNTER-NARRATIVES}


Emotional outbursts, insults and derogatory terms are another important element of counternarratives. Stories with such elements expressed moral repugnance regarding the brutal violence perpetrated by extremists (Cragin, 2014). Derogatory terms and emotional involvement underlined the great importance of the issues at stake and proved the personal commitment of the narrator. The young Muslims whom we interviewed, for example, often described extremists as naïve and simple people who were "brainwashed." They characterized them as "fake, ridiculous and stupid idiots" or as "crazy psychopaths" who were “completely extreme." Such insults were common ways of rejecting extremist groups and an important part of the narrative resistance of young Muslims.

Maryam, a twenty-two-year-old Norwegian-Somali woman, stated with great passion that extremists are "ruining the reputation of Islam," and Melodi said that they are "fucked up people who don't understand life.” In the young Muslims' narratives, jihadists were mainly characterised as what Propp (1968) describes as "villains" or "false heroes" (imposters). Magnus, a twenty-four-year-old Norwegian convert, criticized the IS because of its excessive use of violence, stating, “They are just blood-thirsty. They are completely mad. They only punish because they are used to it, whether they are criminals or gangsters. There must be something wrong with their heads." Others described them as "living in their own little bubble." Amir, a twenty-eight-year-old Norwegian-Pakistani man, described the IS as a group of "provocateurs" without any clear form of vision. He stated that they lived in a fantasy world or, as he put it, "They live in Disneyland." Sometimes, the broad variety of insults and name-calling was so overwhelming that we had the impression that, as opposed to trying to present a consistent narrative, the young Muslims were searching for any available 
derogatory term to describe extremists. The urgent need for young Muslims to disassociate themselves from jihadists often lead to such extreme othering. ${ }^{5}$

Young Muslims often claimed that those who sympathize with extremist groups are brainwashed or mentally ill. Jamal, a twenty-two-year-old Afghani man, explained that "they have something in their minds" that makes it possible. Hassan, a twenty-four-year-old Palestinian man, explained that "the leaders are extreme" and that the people in the IS are not necessarily evil but victims of brainwashing. He emphasized the difference between a general "us" (including the interviewer) and "them": "We are not so kind that we let the others decide, control us and brainwash us." In this way, the dichotomy between Muslim and nonMuslim was replaced with a dichotomy categorizing people as either extremists or peaceful people. Hassan, a twenty-four-year-old Palestinian, compared the IS with other extremist religious groups, saying that they were "just an extremist group, just like other extremist Christian groups in the West. Either way, the IS is just extreme people." Some of the young Muslims we interviewed described extremists as losers or as victims needing help, and they portrayed them in the same way as previous research, as "mindless instruments of someone else" (Joosse et al., 2015, p. 822). Esra, an eighteen-year-old Norwegian-Turkish woman, characterized extremists as being easily manipulable because they were "those who are bullied, who don't have many friends, and who can't tell their friends about their problems, and those who are not included." Such portrayals invalidated the narrative of "jihadi cool" (Picart, 2015) and stripped extremists of agency, masculinity, and anything remotely attractive or desirable, leaving them instead as victims in need of help.

When extremists portrayed themselves as true devout Muslims this evoked strong emotions. Sofia, a nineteen-year-old Norwegian-Somali woman, angrily expressed "I hate, I

\footnotetext{
${ }^{5}$ For an overview over symbolic boundary literature and othering, see e.g. Lamont \& Molnar (2002) and Copes (2016).
} 
hate that they use the name of Islam. And I hate that they try to represent Islam when that's not what it is... I hate them. I only say their punishment lies with God.” She pointed out how IS kills innocent people, but highlighted that "those they kill are mostly Muslims!" and was unable to understand how people could believe such frauds. Some interviewees described extremists as deceiving imposters that hurt innocent people, while calling attention to how "actual" Muslims were the "real victims" of the reign of terror by extremists. These young Muslims thus positioned themselves as the real victims of jihadi terrorism, and argued that mainstream society and the media overlooked this.

Sarah, a twenty-seven-year-old Norwegian-Pakistani woman, harshly defined extremists as savages and "ignorant idiots running around with a shotgun." She also described how "Shaytan is over them. Shaytan is their god. They have gone off the rails." Labelling jihadists as Satan's agents was a way to turn their own rhetoric against themselves. It is also another example of the extreme othering involved in the boundary work of young Muslims. By describing them as the ultimate evil, they drew the clearest and most powerful boundaries possible between themselves and the jihadists. Differentiating in-group from outgroup is not just about the other, but also "a way to reinforce and protect" the self (Dervin, 2012, p. 191). Whether described as genuinely evil or as struggling with mental issues, the main point was that jihadists were fundamentally different from "normal" people and thus that their extremism had little to do with Islam, a major, mainstream religion.

Sometimes, the derogatory terms used in emotional counter-narratives had very specific religious foundations. Combining factual rejection with specific religious insults, some characterized extremist groups as khawarij. This highly offensive term describes a group that appeared in the first century of Islam, creating the first fitna (schism) among Muslims. It is commonly used as a derogatory term to describe organizations with a fundamentalist interpretation of Islam that allows the killing of opponents and the holding of 
extreme religious literalism (Meijer, 2009). Abdullah explained how the Prophet had warned about such groups:

He said, when the day of judgement comes near, there will be a group that will enter the religion and exit it like an arrow goes through a prey. They read the Quran, they pray and all that. But what they read does not hit the heart. They are khawarij. The Prophet called them dogs of hell. The IS has a lot of signs of khawarij, and there are many scholars who call them that.

The term was used to reject violent jihadists, often by participants with a great deal of knowledge about Islam. The use of such terms thus combined the two counter-narrative strategies that we have discussed so far: using an offensive and emotionally laden term and deploying superior Islamic theological knowledge. Khawarij was therefore an effective trope to reject extremist among Muslim youths.

The emotional energy produced by all these condemnations can justify very harsh acts against groups or individuals perceived as being extremists. Aise, a nineteen-year-old Norwegian-Turkish woman, expressed her frustration over foreign fighters going to Syria, saying, "One should really just shoot them. It's impossible to control them.” Describing foreign fighters as evil, mad or uncontrollable in other ways made it necessary to stop them through lethal force. Aisha, a nineteen-year-old Norwegian-Pakistani woman, similarly concluded, "One should go to war with them to kill them. They are absolutely extreme. It's ridiculous." Such recommendations may not have been meant literally and, instead, may have been a way to express frustration and strong emotional involvement in opposing jihadism. Nevertheless, these feelings can be a negative side effect of emotional counter-narratives. The condemnation of extremist groups by our interviewees could sometimes go so far that it 
ended up defending the unlawful use of force to combat them, reflecting a strand of opinion within the majority population.

Jihadi narratives portray jihadists as heroes fighting for justice (Hegghammer, 2017; Sageman, 2008). Derogatory counter-narratives challenge this portrayal and, in an intense othering, describe jihadists as either crazy and blood-thirsty or weak and vulnerable. Emotional counter-narratives frame jihadists as the extremist "other" in a way that more factual counter-narratives do not. Symbolic boundaries are an integrated part of all narratives, but as Copes (2016, p. 194) argues, they are "especially important for those who are members of stigmatized groups or who are socially close to them" (see also Ugelvik, 2014; 2015). Young Muslims might have felt stigmatized by being associated with jihadi organizations through religious affiliation, which may have made them more emphatic when denouncing them. By using derogatory terms and highly emotional language, young Norwegian Muslims drew important boundaries between themselves and stigmatized groups, underlining who they were by making clear who they were not (Copes, Hochstetler \& Williams, 2008).

Emotional counter-narratives are good at mobilizing audiences, and they highlight the significance of the issues at stake. Pathos refers to attempts at persuading by appealing to emotions. Such attempts can be made by telling stories that arouse strong emotions (Presser, 2018) - stories which, as we have emphasized here, reveal the emotional engagement of the narrator him- or herself. The frequent use of derogatory terms shows the intense emotions that were involved in the narrative resistance of young Muslims in Norway. Combined with extreme othering, it can be potentially problematic. As Presser (2013, p. 26) notes, collective stories fuelled by emotion license harm-doing against an "evil other", and the extreme othering we have described above can justify disproportionate counter-terrorism policies and penal sanctions. 


\section{HUMOROUS COUNTER-NARRATIVES}

Ridicule and humour are other important elements in narrative resistance against extremism. Humour is an ambiguous and multifaceted phenomenon, which can be effective as a form of critique targeting members of social out-groups. It also serves a social function, allowing individuals to release tension and to express emotions such as superiority, aggression and hostility (Gruner, 2000). Religious extremism was a sensitive subject, evoking complex feelings. Still the topic was sometimes discussed with laughter in an amused tone among the young Muslims whom we interviewed. Salam, a twenty-five-year-old Moroccan woman, was frustrated but laughingly answered our question of whether she felt that it was her responsibility to defend Islam:

Yes, because every time anything appears on the news about how there has been a bomb or something, the first thing that's written in the newspaper is that the person said “Allahu akbar!” Oh my God! Here we go again! “General assembly! How are we going to solve this situation!?”

The young Muslims viewed excessive media coverage of jihadist terrorism as a problem for them personally. Nala, a twenty-year-old Norwegian-Somali woman, expressed her frustration over the media portrayal of Islam, but she was also able to joke sarcastically about the consequences for her:

N: No, it's, like, "Nala, what are you?” So, I say I'm a Muslim, and then it's, like, “Oh, you are Muslim, what do you think about the IS?" As if that's the first thing that they think about, right?

I: $\quad$ A direct link between the two? 
N: $\quad$ Yes, it's direct. It's very stupid, really. But people ignore all the work Muslims generally do. All the ways they oppose the IS and terrorist groups, fighting against them. It is not taken into consideration at all. Like, if all Muslims were the IS, then we would not have had a stream of refugees, you know. Everyone would be "chilling" in Syria, to put it bluntly. Everyone would have had a great time there because the IS is Islam, right?

The association between Muslims and terrorism was sometimes countered with humour and sarcasm. Expressing out-group hostility by highlighting oppositional attitudes while enhancing in-group solidarity explains how Muslims themselves were victimized by extremists (Gruner, 2000). Houda, a twenty-seven-year-old Norwegian-Lebanese woman, criticized other Muslims for believing in jihadi propaganda or violent interpretations of Islam:

People, please! Hello, God has given us a brain, so read books, read the interpretations. And don't be the person who writes their own book and creates chaos in the world. God does not want chaos. God says the first words we should say to each other are "As-salamu alaykum," which means "Peace be with you." God does not say, “Chaos be with you!” (laughs)

Combining factual rejection with a joke, she made fun of people who believed in jihadi propaganda. By making a joke based on one of the basic phrases that all Muslims know, "Assalamu alaykum," she provided an effective humorous counter-narrative to jihadi narratives. Humour that emphasizes how those made fun of are comically stupid and irrational (Davies, 1988) can work to demonstrate superiority (Gruner, 2000). 
The promise of 72 virgins in paradise for martyrs is an important jihadi narrative and frequently used in the rhetoric of extremist Islamic groups (Halverson et al., 2011). It is also a story frequently referred to in public debates about Islam. Among our participants, it was an important source for ridicule. The sexual undertones probably made it exciting, slightly taboo, and thus particularly fitting for jokes. Mitra, a twenty-five-year-old Norwegian-Iraqi woman, broke into laughter when we mentioned the story about the virgins and stated, "Um, yes... yes, assume I see it... it's in a way a very childish approach to death, a little, like, 'Oh, I know I'm gonna get this, so just let me kill a non-Muslim." She paused for a while but then continued to elaborate on her thoughts of what it meant to be a "real martyr."

Humour and laughter can reduce the tension or stress associated with awkward situations and sensitive themes. Laughter and jokes can release negative energy and help make it possible to talk about difficult subjects (Lynch, 2002). This was evident, for example, when the participants explained the concept of jihad as being an inner struggle and then used laughter to transition to the concept of violent jihad. We asked Mustafa what jihad meant to him, and he explained how "jihad is working on yourself, striving in everyday life. You strive when you study, you strive when you work, that is jihad." He then laughed and asked, "But it is probably the 'holy war' you're looking for, al-Harb al-Muqaddasa?'” reference to a controversial interpretation of the concept of "holy war" in Islam (Kabbani, 2006). He thus implicitly criticized us by making a joke implying that we were mainly interested in the violent aspects of Islam. Humour works as a social corrective (Sandberg \& Tutenges, 2018), in this case by posing a critique that is less direct and therefore easier to convey.

Anton, a twenty-five-year-old Norwegian-Moroccan man, was also familiar with the story about the virgins and laughingly stated, "Rewarded with 72 virgins and so on... Yeah, I

\footnotetext{
${ }^{6}$ Referring to the Arabic term for jihad, which does not occur in the Quran (Kabbani, 2006).
} 
don't know. It would have been 'nice' with 72 virgins. But I can't handle one, let alone if you are supposed to have 72.” In addition to releasing tension, jokes can express a sense of superiority (Gruner, 2000). In broad terms, humour is based on aggression and hostility (Martin, 2007), which was evident when young Muslims combined factual or emotional counter-narratives to make fun of extremists by criticizing their lack of theological knowledge, their intellectual capacity or their moral values. Doing so empowered young Muslims by constructing their status as "the storyteller who knows better," who can humorously see through jihadi propaganda (Joosse et al., 2015, p. 825).

Our distinction between different counter-narratives, utilized by young Muslims, is analytical. In the "real world," these forms of narrative resistance are closely intertwined. For example, when Sana, in what we described as a factual counter-narrative above, asked, "Where in the Quran does it say that you must kill a baby and the world will be better?," she questioned the jihadists' knowledge of Islam by using a highly emotional trope. Mentioning killing a baby is also ambiguous and in this context open to different interpretations, expressing either humorous critique, tragic despair or both. Laughter and tears are closely connected, and humour often carries important messages and critiques (Sandberg \& Tutenges, 2018). Many jokes about jihadists also played on the extremists' lack of knowledge about Islam, and derogatory terms and insults sometimes had a comic dimension. Because of the inherent ambiguity in much humour, the ways in which different forms of resistance are connected are therefore especially evident in humorous narratives.

\section{SILENCING AS RESISTANCE}

Narrative resistance can also include silence. Many young Muslims did not "want to know" or talk too much about the IS or other extremist groups. They felt that these groups did not 
deserve their attention, and they tried to ignore them to make a political statement. As Presser (2013, p. 119) emphasizes, that which is not said speak volumes. ${ }^{7}$ Many young Muslims also considered detailed knowledge of groups such as the IS, al-Qaeda, al-Shabaab or Taliban to be redundant and were frustrated over the expectation that Muslims should distance themselves from terrorism committed in the name of Islam. For example, Amina, an eighteen-year-old Norwegian-Somali woman, explained that the constant pressure to reject jihadism was exhausting, but she said that she had found a solution:

Now, I don't care anymore. I don't feel like explaining. It's one thing when a person asks you about something, but it annoyed me when it was always brought up during class. It was always the most, like, extreme stuff, like, "What do you think, Amina?," and I'm, like, "Out of all thirty students, why do you ask me?," get it? It was very frustrating. It was like you were supposed to have opinions about everything, and maybe, like, you didn’t know. It was, like, 'No, a Muslim must have an already complete identity and know everything from A to Z." So, it was sort of like, "No!"

Amina's story shows how the pressures to know a great deal about or to denounce jihadism sometimes resulted in Muslims attempting to disregard the subject entirely. Ahmed, a twentyfour-year-old Norwegian-Afghani man, expressed a similar point of view, saying, "I don’t think they represent Islam, and I'm not even interested in reading about them. So, why should I waste any energy on it?” Abdul, a twenty-one-year-old Norwegian-Kurdish man, also reflected this attitude when asked about the IS and radicalization on the internet:

\footnotetext{
${ }^{7}$ See also her chapter in this volume.
} 
I don't remember any websites because I want to block it. I keep away from it. I don't remember any websites. I don't remember, I'm so terrible with those names. Because they don't have any relevance in my life, get it? So, that's why I don't put any emphasis on it. I just put it in the trashcan in my memory.

Abdul proceeded to discuss theological questions in Islam and elaborated between right and wrong. However, when asked in detail about jihadist organizations, he had problems recollecting details:

A: I've probably heard a lot, but I don't involve myself with it, but I'm just, like, “Oh no, not this again." So, it's like that. It's not like I involve myself with it and "It's so interesting now, I'm going on jihad" [laughter]. I'm not exactly like that.

I: No, you “delete it from your memory" and don't bother with it?

A: Yes, it's not so... It's not relevant. And it's not relevant in my everyday life. Why should I care about wrong knowledge? That's just stupid.

Abdul's reply can be viewed as another example of how intertwined the different counternarratives in narrative resistance are. When he stated that he does not care about jihadist organizations, the reason he offered was that they have "wrong knowledge," thus emphasizing their faulty theological command. He also makes a sarcastic joke in the middle of a narrative emphasizing the importance of ignoring extremist organizations. Most importantly, however, jihadi rhetoric was viewed as either irrelevant or wrong, and many young Muslims therefore did not want to waste energy on remembering details or refuting the religious claims promoted by such organizations, even when the young people clearly 
disagreed. This refusal can be described as resistance by silencing. Along with humour and ridicule, it is an important - but hitherto undescribed - way of rejecting extremism.

As demonstrated above, in a narrative analysis, counter-narrative forms are analytically separable categories that are nevertheless closely intertwined. The close relationship between these forms of narrative resistance can be observed in the way in which the young Muslims alternated between them in our interviews. This was even the case for silencing. Some participants who stated that they really did not want to talk about extremists could subsequently proceed to talk about them at length. Silencing as resistance can therefore be viewed as narrative resistance in two different ways. First, it is "actual" silencing, where these organizations are ignored and not talked about. Second, it is a more explicit counternarrative verbally stating that these organizations are so obscure that they do not merit any attention. This kind of silencing was closely associated with other insults and othering more generally.

\section{CONCLUSION}

Interviews with young Norwegian Muslims reveal a broad narrative repertoire for rejecting religious extremism. The counter-narratives they told reflect general forms of narrative resistance that carry out very different types of work for the narrator. Factual counternarratives calmly and factually explain that the other group is wrong. Such stories appeal to the mind and show that the narrators are intellectually "above" their opponents. Emotional counter-narratives, on the other hand, come with and appeal to the passions. They often include derogatory terms and familiar storied characters to construct an "other" who is evil, mad or weak. Humorous counter-narratives consist of all kinds of jokes and snubs intended to be funny. Using humour makes it easier to talk about difficult topics and removes some of the 
gravity in sensitive discussions; furthermore, it is a way of demonstrating superiority and entertaining audiences through both stories and humorous narrative performances. Finally, silencing as resistance or a more explicit narrative about not wanting to talk about particular people, organizations or topics is a way of denying them significance in society, attention and, not the least, meaning in the narrators' own lives.

The narrative resistance and counter-narratives revealed in this chapter can be viewed as both "narratives of gentle defiance and resistance" (Andrews, 2004, p. 5). For the young Muslims whom we interviewed, it was common to alternate between seriously and factually rejecting the claims of jihadists and insulting, making fun of, or even completely ignoring them; sometimes, these strategies changed within a short period of time. Some of these narrative responses lean more towards active resistance, while others may be better described as gentle defiance. However, we argue that their prominence across narratives and the spontaneity with which they were shared suggests that they were of great importance to the narrators. Even the attempts to ignore extremist organizations and rhetoric were clearly driven more by deep discontent than by ignorance, which is the main reason why we describe such attempts as important forms of resistance to extremism.

A possible critique of our argument is that we know little of what happens outside interviews, and that the stories we have identified are produced in the interview setting for the researcher. Although reasonable, such critique shows little sensitivity to the social character of narratives. People have a limited number of stories to their disposal, and the ones they have are co-constructed or sometimes even determined by the society and community they live in (Foucault, 1970). Although interviewees strategically amend stories within interviews, it is difficult, if not impossible, to "invent" new narratives on the spot to please interviewers. We believe that the strong emotions displayed in our interviews revealed how much was at stake for the narrator. The overall strength and magnitude of the counter-narratives we 
identified speak clearly to the depth and significance of opposition to extremism in Muslim communities. These qualities also suggest that the Muslim community has "already developed narrative tools that render it largely resistant to the radicalization process" (Joosse et al., 2015, p. 815). While this does not imply immunity against radicalization, these counter-narratives are powerful resources in an ongoing narrative struggle concerning the meaning of Islam in Muslim communities.

We believe that narrative criminological studies can benefit from delving more into counter-narratives (Presser 2018, p. 144). Large qualitative data sampling achieved through team research is one way to do this. It demands more resources than smaller interview-based studies, but if one has the time and money, having a large sample will make it possible to paint a broader picture of what is studied and to achieve more variation. It can also make it easier to decide which stories are important in a particular group, culture or society, and avoid speculations about stories being told because of specific interview constellations. Most importantly, a research team consisting of individuals with different expertise, background and knowledge is an invaluable resource and source of inspiration when doing interviews or ethnography and when discussing and interpreting preliminary results.

Studying counter-narratives can be helpful for understanding why crime, and especially serious violence, is not the rule. It can also help make all kinds of stigmatized populations less marginal by showing the many ways in which crime and harm are "fought from within" - and the potential dangers of such opposition. Extreme othering has the potential to license disproportional harm in the name of good. Emphasizing positive resistance and the people and processes that constrain harm can help in moving away from the overall negative focus of most criminology studies. In its search for the causes of crime, much research in criminology has been overlooking societal resistance and opposition to harmful action. The multitude of ways in which crime and harm is rejected should be at the 
RUNNING HEADER: Narrative Resistance

core for anyone interested in understanding what instigates, sustains, or impacts avoidance of harmful action. 


\section{References:}

Ahmed, S., \& Matthes, J. (2017). Media representation of Muslims and Islam from 2000 to 2015: A meta-analysis. The International Communication Gazette, 79(3), 219-244. Doi: $10.1177 / 1748048516656305$.

Andersen, J. C. \& Sandberg, S. (2018). Islamic State Propaganda: Between Social Movement Framing and Subcultural Provocation. Terrorism and Political Violence, 1-21. Doi: 10.1080/09546553.2018.1484356.

Andrews, M. (2004). Counter-narratives and the power to oppose. In M. Bamberg and M. Andrews (Eds): Considering Counter-Narratives: Narrating, resisting, making sense (p. 1-7). Amsterdam: John Benjamins Publishing Company.

Andrews, M. (2002). Memories of mother: Counter-narratives of early maternal influence. Narrative Inquiry, 12(1), 7-21. Doi: 10.1075/ni.12.1.04and.

Aristotle (2010), Rhetoric. City: ReadaClassic.

Aydin, C. (2017). The Idea of the Muslim World: A Global Intellectual History. Cambridge: Harvard University Press.

Bahari, M. \& Hassan, M. H. (2014). The Black Flag Myth: An Analysis from Hadith Studies. Counter Terrorist Trends and Analysis, 6(8), 15-20.

Bamberg, M. (2004). Considering counter narratives. In M. Bamberg and M. Andrews (Eds): Considering Counter-Narratives: Narrating, resisting, making sense (p. 351-372). Amsterdam: John Benjamins Publishing Company.

Barlas, A. (2002). "Believing in Women” in Islam: Unreading Patriarchal Interpretations of the Qur'an. Austin: University of Texas Press.

Baumann, R. (1986). Story, performance, and event. Contextual studies of oral narrative. Cambridge: Cambridge University Press.

Bucerius, S. (2013). Becoming a "Trusted Outsider": Gender, Ethnicity, and Inequality in Ethnographic Research. Journal of Contemporary Ethnography 42(6), 690-721. Doi: 10.1177/0891241613497747.

Byman, D. (2015). Al Qaeda, the Islamic State, and the Global Jihadist Movement: What Everyone Needs to Know. Oxford: Oxford University Press.

Copes, H. (2016). A narrative approach to studying symbolic boundaries among drug users: A qualitative meta-synthesis. Crime, Media, Culture, 12(2), 193-213. Doi: $10.1177 / 1741659016641720$. 
Copes, H., Hochstetler, A., \& Williams, J. P. (2008). “We Weren’t Like No Regular Dope Fiends": Negotiating Hustler and Crackhead Identities. Social Problems, 55(1), 524270. Doi: $10.1525 / \mathrm{sp} .2008 .55 .2 .254$.

Cragin, R. K. (2014). Resisting Violent Extremism: A Conceptual Model for NonRadicalization. Terrorism and Political Violence, 26(2), 337-353. Doi: $10.1080 / 09546553.2012 .714820$

Damsa, D. \& Ugelvik, T. (2017). A Difference That Makes a Difference? Reflexivity and Researcher Effects in an All-Foreign Prison. International Journal of Qualitative Methods, 16(1), 1-10. Doi: 10.1177/1609406917713132.

Davies, C. (1988). Stupidity and Rationality: Jokes from the Iron Cage. In C. Powell and G. E. C. Paton (Eds.): Humor in Society. Resistance and Control. London: Macmillan Press. Dervin, F. (2012). Cultural identity, representation and othering. In J. Jackson (Ed.): The Routledge Handbook of Language and Intercultural Communication. Abingdon: Routledge.

Ekman, M. (2015). Online Islamophobia and the politics of fear: manufacturing the green scare. Ethnic and Racial Studies, 38(11), 1986-2002. Doi: 10.1080/01419870.2015.1021264.

Essers, C. \& Benschop, Y. (2009). Muslim businesswomen doing boundary work: The negotiation of Islam, gender and ethnicity within entrepreneurial context. Human Relations, 62(3), 403-423. Doi: 10.1177/0018726708101042.

Fleetwood, J. (2016). Narrative habitus: Thinking through structure/agency in the narratives of offenders. Crime, Media, Culture, 12(2), 173-192. Doi: 10.1177/1741659016653643.

Foucault, M. (1970). The Order of Things. New York: Pantheon.

Gruner, C. R. (2000). The game of humor: A comprehensive theory of why we laugh. New Brunswick, NJ: Transaction Publishing House.

Halverson, J. R., Goodall, H. L., \& Corman, S. R. (2011). Master narratives of Islamist extremism. New York: Palgrave Macmillan.

Hegghammer, T. (2017). Jihadi Culture: The Art of Social Practices of Militant Islamists. Cambridge: Cambridge University Press.

Jackson, R. (2007). Constructing Enemies: 'Islamic Terrorism' in Political and Academic Discourse in Political and Academic Discourse. Government and Opposition, 42(3), 394-426. Doi: 10.1111/j.1477-7053.2007.00229.x. 
Joosse, P., Bucerius, S. M., \& Thompson, S. K. (2015). Narratives and counternarratives: Somali-Canadians on recruitment as foreign fighters to Al-Shabaab. British Journal of Criminology, 55(4), 811-832.

Kabbani, S. M. H. (2006). Jihad in Islam. In V. Cornell (Ed.): Voices of Islam (p. 205-256). Westport: Greenwood Publishing.

Karmon, E. (2015). Islamic State and al-Qaeda Competing for Hearts \& Minds. Perspectives on Terrorism, 9(2), 71-79.

Kearns, E., Betus, A., \& Lemieux, A. (2017). Why Do Some Terrorist Attacks Receive More Media Attention Than Others? Social Science Research Network. Retrieved from: https://ssrn.com/abstract $=2928138$

Laclau, E. \& Mouffe, C. (1985). Hegemony and Socialist Strategy. London: Verso.

Lamont M. \& Molnar, V. (2002). The Study of Boundaries in the Social Sciences. Annual Review of Sociology, 28(1), 167-195. Doi: 10.1146/annurev.soc.28.110601.141107.

Leuprecht, C., Hataley, T., Moskalenko, S., \& McCauley, C. (2009). Winning the Battle but Losing the War? Narrative and Counter-Narratives Strategy. Perspectives on Terrorism, 3(2), 25-35.

Lynch, O. H. (2002). Humorous communication: Finding a place for humor in communication research. Communication Theory, 12(4), 423-445. Doi: 10.1111/j.14682885.2002.tb00277.x.

Maidment, J. (2017). Muslims must do more than just 'condemn' terror attacks, Sajid Javid says. The Telegraph. Retrieved from: https://www.telegraph.co.uk/news/2017/06/05/muslims-must-do-just-condemn-terrorattacks-sajid-javid-says/ (accessed 10.11.2018).

Martin, R. A. (2007). The Psychology of Humor: An Integrative Approach. Burlington: Elsevier.

Maruna, S. (2001). Making Good. How Ex-Convicts Reform and Rebuild Their Lives. Washington, DC: American Psychological Association Press.

McCants, W. (2015). The ISIS Apoclypse: The history, strategy, and doomsday vision of the Islamic State. New York: St. Martins Press.

Meijer, R. (2009). Global Salafism: Islam's new religious movement. London: Hurst. Mythen, G., Walklate, S., \& Khan, F. (2012). 'Why Should We Have to Prove We're Alright?': Counter-terrorism, Risk and Partial Securities. Sociology 47(2), 383-398. Doi: 10.1177/0038038512444811. 
Page, M., Challita, L. \& Harris, A. (2011). Al Qaeda in the Arabian Peninsula: Framing Narratives and Prescriptions. Studies in Conflict \& Terrorism, 23(2), 150-172. Doi: 10.1080/09546553.2010.526039.

Picart, C. J. S. (2015). "Jihad Cool/Jihad Chic": The Roles of the Internet and Imagined Relations in the Self-Radicalization of Colleen LaRose (Jihad Jane). Societies, 5(2), 354-383. Doi: 10.3390/soc5020354.

Polletta, F., Chen, P. C. B., Gardner, B. G. \& Motes, A. (2011). The Sociology of Storytelling. Annual Review of Sociology, 37, 109-130.

Presser, L. (2018). Inside Story. How Narratives Drive Mass Harm. Oakland: University of California Press.

Presser, L. (2013). Why We Harm. New Brunswick, NJ and London: Rutgers University Press.

Presser, L. (2009). The narratives of offenders. Theoretical Criminology, 13(2), 177-200. Doi: $10.1177 / 1362480609102878$.

Presser, L. \& Sandberg, S. (2015). Introduction: What is the Story?. In L. Presser \& S. Sandberg (Eds.): Narrative criminology: Understanding stories of crime (p. 1-22). New York: New York University Press.

Propp, V. (1968). Morphology of the Folk Tale. Austin, TX: University of Texas Press. Sageman, M. (2008). Leaderless Jihad: Terror Networks in the Twenty-First Century. Philadelphia: University of Pennsylvania Press.

Sandberg, S. (2016). The importance of stories untold: Life-story, event-story and trope. Crime, Media, Culture, 12(2), 153-171. Doi: 10.1177/1741659016639355.

Sandberg, S., \& Tutenges, S. (2018). Laughter in Stories of Crime and Tragedy: The Importance of Humor for Marginalized Populations. Social Problems, 1-16. Doi: 10.1093/socpro/spy019.

Sandberg, S., Andersen, J. C., Gasser, T. L. U., Linge, M., Mohamed, I. A. A., Shokr, S., \& Tutenges, S. (2018). Unge Muslimske Stemmer: Om Tro og Ekstremisme [Young Muslim Voices: On Faith and Extremism]. Oslo: Oslo University Press.

Shaffer, R. (2016). Jihad and Counter-Jihad in Europe: Islamic Radicals, Right-Wing Extremists, and Counter-Terrorism Responses. Terrorism and Political Violence, 28(2), 383-394. Doi: 10.1080/09546553.2016.1140538.

Talbot, J., Bibace, R., Bokhour, B., \& Bamberg, M. (1996). Affirmation and resistance of dominant discourses: The rhetorical construction of pregnancy. Journal of Narrative and Life History. 6(3), 225-251. Doi: 10.1075/jnlh.6.3.02aff. 
Ugelvik, T. (2015). The Rapist and the Proper Criminal: The Exclusion of Immoral Others as Narrative Work on the Self. In L. Presser \& S. Sandberg (Eds.): Narrative Criminology: Understanding Stories of Crime (p. 23-41). New York University Press: New York \& London.

Ugelvik, T. (2014). 'Be a man. Not a bitch.' Snitching the inmate code and the narrative reconstruction of masculinity in a Norwegian prison. In I. Lander, S. Ravn \& N. Jon (Eds.): Masculinities in the Criminological Field (p. 69-82). Routledge: London \& New York.

van Es, M. A. (2018). Muslims Denouncing Violent Extremism. Journal of Muslims in Europe, 7(2), 142-166. Doi: 10.1163/22117954-12341374.

Vestel, V. \& A. Bakken (2016). Holdninger til ekstremisme. Resultater fra Ung i Oslo 2015 (NOVA/2016).

Von Sikorski, C., Schmuck, D., Matthes, J., \& Binder, A. (2017). "Muslims are not Terrorists": Islamic State Coverage, Journalistic Differentiation Between Terrorism and Islam, Fear Reactions, and Attitudes Toward Muslims. Mass Communications and Society, 20(6), 825-848. Doi: 10.1080/15205436.2017.1342131.

Østeby, L. \& Dalgard, A. B. (2017, november 22). Det religiфse mangfoldet. 4 prosent Muslimer i Norge?. Retrieved from: https://www.ssb.no/befolkning/artikler-ogpublikasjoner/4-prosent-muslimer-i-norge (accessed 26.04.2018). 